\title{
OEIS Complex
}

National Cancer Institute

\section{Source}

National Cancer Institute. OEIS Complex. NCI Thesaurus. Code C99142.

A rare combination of congenital abnormalities that includes omphalocele, cloacal exstrophy, imperforate anus, and spine abnormalities. 